\title{
The Effects of Globalization on Entrepreneurial Revitalization of Main Urban Areas - Case of Croatia
}

\author{
Domagoj Hruška ${ }^{1, *}$, Tihomir Luković ${ }^{2}$, and Damir Piplica ${ }^{3}$ \\ ${ }^{1}$ University of Zagreb, Faculty of Econonics and Business, Trg. J.F.Kennedy 6, 10000 Zagreb, \\ Croatia \\ ${ }^{2}$ University College Aspira, Mike Tripala 6, 21000 Split, Croatia \\ ${ }^{3}$ University of Split, University Department for Forensic Sciences Split, Ruđera Boškovića 33, 21000 \\ Split, Croatia
}

\begin{abstract}
Research background: The paper argues how the sustainable development of entrepreneurship in urban areas is based on four cornerstones: corruption, size of urban areas, industrial structure and cultural biases. Corruption is a significant social and economic issue that has crippling effect for entrepreneurship. Further on, the superiority of larger cities in generating advanced economies has been recognized since the time of the ancient Greek and medieval Italian city-states, however it is not clear if the same is applicable today as well. Third cornerstone of entrepreneurial development in main urban areas is the industrial structure of these areas. Lastly, the values that drive entrepreneurial action and form entrepreneurial environments are embedded in wider national culture.

Purpose of the article: The aim of the paper is to investigate and describe pivotal influences on entrepreneurial activity as an impetus of sustainable economic development in globalized environment of transition economy urban areas.

Methods: The four factors that influence the level of sustainable development of entrepreneurship in urban areas: level of perceived corruption, size of urban areas, industrial structure and cultural biases are described as well as the correlation between level of entrepreneurial activity and each of these crucial elements of urban revitalization.

Findings \& Value added: By examining antecedents and consequences of economic and social circumstances that define environment for fostering entrepreneurial activity in main urban areas in Croatia the paper provides comprehensive tool for strategy development that can be used by policy makers and entrepreneurs alike.
\end{abstract}

Keywords: Entrepreneurial Revitalization; Urban Areas; Globalization; Croatia

\footnotetext{
*Corresponding author: dhruska@,net.efzg.hr
} 
JEL Classification: $L 26,018, M 10$

\section{Introduction}

Influence of globalizing forces on development of entrepreneurship is usually viewed through the lens of international economy and competitive advantage of nations [1-6]. In this paper, however, we take a different approach and claim that the factors which yield the biggest influence on fostering entrepreneurial spirit are level of corruption, size of urban areas, industrial structure and cultural biases. Due to the fact that the analysis of the entire set of influences would necessary go beyond the scope of a single paper, we focus on the influence of corruption on entrepreneurial activity. By using the Spearman's rank correlation coefficient to obtain evidence weather there is a link between corruption, intensity of business activity, structure of business activity and motivation for starting a new business venture we are trying to shed light to this complex and important area of economic development.

Entrepreneurial activity is what drives economic prosperity. We look at small and medium companies. And observe relation between entrepreneurial revitalization from the perspective of current business activity and motivation of starting a new business venture and reported levels of corruption, measured by from the other perspective.

Croatia, as an economy in transition, is susceptible to corruption and so far it cannot find a way organize its economic and legal system, in which corruption would, if not prevented, be at least high risk for the perpetrators. In such unfavourable conditions, corruption seems to have become part of the entire state system, which directs the problem towards political power, as discussed by numerous authors [17-21]. According to the Global Entrepreneurship Monitor (GEM 2018/2019 Global Report [22]) (Figure 1) major problems of Croatian entrepreneurship can be found in areas of culture and social norms, internal market burdens of entry regulation, government policies and entrepreneurial education in post-school stage. Key factors that determine dynamics of economic development as described in this paper tackle these burning issues of entrepreneurial development.

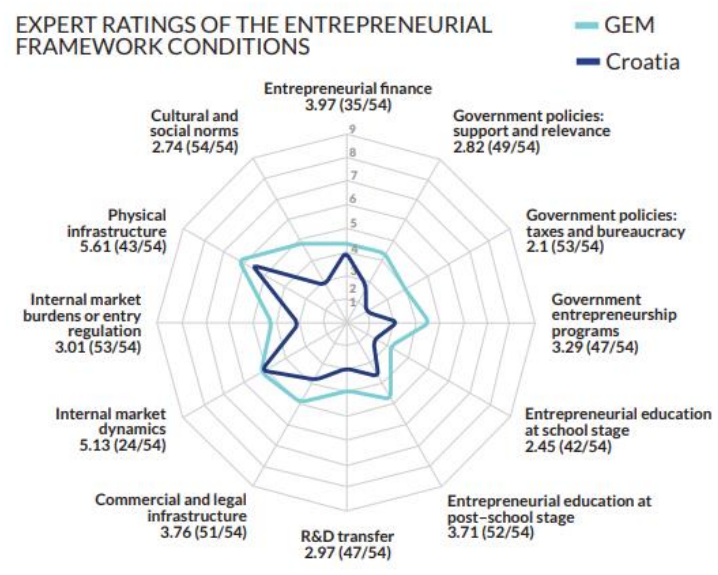

EFCs scale: 1 = very inadequate insufficient status, 9 = very adequate sufficient status Rank out of 54 recorded in brackets

Fig. 1. Expert ratings of the entrepreneurial framework conditions - Croatia and GEM average; Source: Bosma N. Kelley D. (2019). Global Entrepreneurship Monitor 2018/2019 Global Report, GEM. p. 75 [22] 
The detrimental impact of corruption on economic growth has been confirmed by a number of other authors, such as Shleifer and Vishny [7]) who have conducted and published interesting research conducted in Russia, the Philippines and Africa, concluding that corruption is an important cost to society. The negative impact of corruption on economic growth is also confirmed by Sachs and Warner [8], Mauro [9], Brunetti [10], Kaufmann, Kraay and Zoido-Lobaton [11], Leite and Weidmann [12], as and GyimahBrempong [13], Neeman, Paserman and Simhon [14], Welsch [15], as well as Pellegrini and Gerlagh [16].

Croatian Corruption Perception Index (CPI) according to the Transparency International. Perception of corruption in transition counties is relatively high. Out of all EU transition economies, Estonia has the lowest corruption index. The macro-European region of Baltic states is the place where Europe's strongest and most cooperative economies in transition are found. This collaboration is based on a logical life attitude, which is that it is not good to have a poor neighbor if you are rich because it always implies trouble. As one can see, Denmark, Finland and Sweden are leading European and world economies in terms of eliminating corruption (Table 2).

Table 1. Corruption Perception Index (CPI)according to the Transparency International data from 2008 to 2018

\begin{tabular}{|l|l|l|l|l|l|l|l|l|l|l|r|r|}
\hline Country & $\mathbf{2 0 0 8}$ & $\mathbf{2 0 0 9}$ & $\mathbf{2 0 1 0}$ & $\mathbf{2 0 1 1}$ & $\mathbf{2 0 1 2}$ & $\mathbf{2 0 1 3}$ & $\mathbf{2 0 1 4}$ & $\mathbf{2 0 1 5}$ & $\mathbf{2 0 1 6}$ & $\mathbf{2 0 1 7}$ & $\mathbf{2 0 1 8}$ \\
\hline Denmark & & & & & 90 & 91 & 92 & 91 & 90 & 88 & 88 \\
\hline Finland & & & & & 90 & 89 & 89 & 89 & 89 & 85 & 95 \\
\hline Sweden & & & & & 88 & 89 & 87 & 89 & 88 & 84 & 85 \\
\hline & & & & & & & & & & & \\
\hline Austria & 81 & 79 & 79 & 78 & 69 & 69 & 72 & 76 & 75 & & \\
\hline & & & & & & & & & & & \\
\hline Slovenia & 67 & 66 & 64 & 59 & 61 & 57 & 58 & 60 & 61 & 61 & 60 \\
\hline Estonia & 66 & 66 & 65 & 64 & 64 & 68 & 69 & 70 & 70 & 71 & 73 \\
\hline Czech R & 52 & 49 & 46 & 44 & 49 & 48 & 51 & 56 & 55 & 57 & 59 \\
\hline Hungary & 51 & 51 & 47 & 46 & 55 & 54 & 54 & 51 & 48 & 45 & 46 \\
\hline Latvia & 50 & 45 & 43 & 42 & 49 & 53 & 55 & 56 & 57 & 58 & 58 \\
\hline Slovakia & 50 & 45 & 43 & 40 & 46 & 47 & 50 & 51 & 51 & 50 & 50 \\
\hline Lithuania & 46 & 49 & 50 & 48 & 54 & 57 & 58 & 59 & 59 & 59 & 59 \\
\hline Poland & 46 & 50 & 53 & 55 & 58 & 60 & 61 & 63 & 62 & 60 & 60 \\
\hline Croatia & $\mathbf{4 4}$ & $\mathbf{4 1}$ & $\mathbf{4 1}$ & $\mathbf{4 0}$ & $\mathbf{4 6}$ & $\mathbf{4 8}$ & $\mathbf{4 8}$ & $\mathbf{5 1}$ & $\mathbf{4 9}$ & $\mathbf{4 9}$ & $\mathbf{4 8}$ \\
\hline Romania & 38 & 38 & 37 & 36 & 44 & 43 & 43 & 46 & 48 & 48 & 47 \\
\hline Bulgaria & 36 & 38 & 36 & 33 & 41 & 41 & 43 & 41 & 41 & 43 & 42 \\
\hline
\end{tabular}

Source: Transparency International. Notice: higher index signifies lower level of perceived corruption

The phenomenon of corruption in Croatian society is mainly viewed in the criminal law context. In recent years, however, special attention has been paid to the phenomenon of economic corruption. There is undoubtedly a strong increase in the interest of domestic and especially foreign economists in researching the impact of corruption on a number of macro and microeconomic indicators, such as: GDP per capita, economic growth rate, investment, shadow economy, foreign direct investment, public expenditure, and more. Of course, not only can the impact of corruption be explained by the movement of particular economic indicators, but such a causal link cannot be fully explained without understanding this relationship.

\section{Methods}

We use the Spearman's rank correlation coefficient in order to discover the strength of a link between the factors that influence the level of sustainable development of entrepreneurship in urban areas. More specifically, since we focus on the influence of corruption, we are using the Spearman's rank correlation coefficient to observe wheatear 
there is a degree of correlation, or the degree of non-correlation between: corruption, intensity of business activity, structure of business activity and motivation for starting a new business venture.

In order to properly address these questions, we are using ranks in accordance regions of Croatia. Although in the Nomenclature of Territorial Units for Statistics (NUTS) of the European Union Croatia consists of only two region: Jadranska Hrvatska (adriatic region) and Kontinentalna Hrvatska (continental part of Croatia), for our purpose we are using division at six regions which are formed from grouping of Croatian counties and the City of Zagreb. The six regions, formed according to the criterion of geographical and historical understanding of the regional structure of Croatia, are adapted from the longitudinal research Global Entrepreneurship Monitor Croatia conducted by CEPOR SMEs and Entrepreneurship Policy Center. The six observed regions together with the counties that constitute these regions are presented in Table 1.

Table 2. Division of Croatia to the regions and counties that constitute them

\begin{tabular}{|c|c|}
\hline Region & Counties that constitute regions \\
\hline Zagreb and surroundings & City of Zagreb, Zagreb County \\
\hline Slavonia and Baranja & $\begin{array}{r}\text { Pozega and Slavonia County, Brod and Posavina County, } \\
\text { Osijek and Baranja County, Vukovar and Srijem County }\end{array}$ \\
\hline Northern Croatia & $\begin{array}{c}\text { Medjimurje County, Varazdin County, Krapina and Zagorje } \\
\text { County, Koprivnica and Krizevci County, Bjelovar and } \\
\text { Bilogora County, Virovitica and Podravina County }\end{array}$ \\
\hline Lika and Banovina & $\begin{array}{c}\text { Lika i Senj County, Sisak and Moslavina County, Karlovac } \\
\text { County }\end{array}$ \\
\hline Istria, Primorje and Gorski Kotar & Istria County, Primorsko-Goranska County \\
\hline Dalmatia & $\begin{array}{r}\text { Zadar County, Sibenik and Knin County, Split and Dalmatia } \\
\text { County, Dubrovnik and Neretva County }\end{array}$ \\
\hline
\end{tabular}

In order to address the influence of corruption on entrepreneurial activity we have gather data from different sources.

\subsection{Data sources for determining level of entrepreneurial activity in observed Croatian regions}

For needed data on the structure of entrepreneurs by regions and entrepreneurs Motivation to start an entrepreneurship we using data from the Global Entrepreneurship Monitor Consortium longitudinal research study in which Croatia is included since 2002. Main aim of the research project is to monitor key components of national entrepreneurial capacity on annual basis (measured by intentions and intensity of starting business ventures, share of growing businesses and quality of entrepreneurial environment).

In the Table 3 we can see levels of entrepreneurial activity of six Croatian regions from two perspectives - new entrepreneurial activity and motivational index, together with the development index and unemployment rate of these regions. 
Table 3. Development profiles of regions in Croatia, 2017

\begin{tabular}{|c|c|c|c|c|c|c|c|c|c|c|}
\hline \multirow[b]{2}{*}{ Region } & \multicolumn{2}{|c|}{ Development Indeks } & \multicolumn{2}{|c|}{ GDP pc } & \multicolumn{2}{|c|}{ Unemployment } & \multicolumn{4}{|c|}{ Enterprenurial activity } \\
\hline & $\%$ & Rank & EUR & Rank & $\%$ & Rank & New enterpre & ctivity & Motivational Indeks & \\
\hline Zagreb and surroundings & 155,34 & 1 & 13422 & 1 & 8,1 & 5 & 9,9 & 2 & 2,6 & 2 \\
\hline Northern Croatia & 52,88 & 5 & 7795 & 5 & 12,93 & 4 & 8,8 & 5 & 1,4 & 4 \\
\hline Lika and Banovina & 53,29 & 4 & 7962 & 4 & 18,6 & 2 & 6,7 & 6 & 0,9 & 5 \\
\hline Istria, Primorje and Gorski Kotar & 148,01 & 2 & 12998 & 2 & 6,3 & 6 & 9,8 & 3 & 4,8 & 1 \\
\hline
\end{tabular}

Source: Singer, S., Šarlija, N., Pfeifer S., Oberman Peterka, S. (2018). What makes Croatia a (non)entrepreneurial country? GEM Croatia 2017, CEPOR - SMEs and Entrepreneurship Policy Center, p. 67 [23]

Motivational index is calculated as ratio of early-stage entrepreneurial ventures started because of perceived opportunity or out of necessity and it contributes to the understanding of the level of (non) development of individual regions. We can see that regions of Lika and Banovina and Slavonia and Baranja show lowest motivational indexes and a accompanied by a low level of development, a low level of GDP per capita and high unemployment.

Besides these data we also use data from Financial Agency (FINA) in respect to number of enterprises and Croatian Central Bureau of Statistics for values of goods sold.

\subsection{Data sources for determining level of corruption in observed Croatian regions}

Determining level of corruption is notoriously problematic due to the fact that it is a criminal activity which hinders adequate reporting even in absolutely anonymous systems of data gathering. Instead of determining level of perceived corruption in observed Croatian regions have used data on corruption offenses published by Ministry of the Interior of Republic of Croatia in their yearly publication.

Table 4. Corruption offenses in Croatia by form of commission in 2019

\begin{tabular}{|c|c|c|c|c|c|c|c|c|}
\hline \multirow{3}{*}{ Corruption offences } & \multicolumn{3}{|c|}{ Reported criminal offenses } & \multicolumn{3}{|c|}{ Solved criminal offenses } & \multirow{3}{*}{$\begin{array}{c}\% \text { of total } \\
\text { number of } \\
\text { reported cases }\end{array}$} & \multirow{3}{*}{$\begin{array}{c}\text { Material } \\
\text { damage in } \\
2019\end{array}$} \\
\hline & \multicolumn{2}{|c|}{ Number of offences } & \multirow{2}{*}{$+-\%$} & \multicolumn{2}{|c|}{ Number of offences } & \multirow{2}{*}{$+-\%$} & & \\
\hline & 2018 & 2019 & & 2018 & 2019 & & & \\
\hline Accepting bribes in business & & 131 & & & 131 & & 16,7 & 1.961 .256 \\
\hline Bribery in business & & 131 & & & 131 & & 16,7 & 934.474 \\
\hline $\begin{array}{l}\text { Abuse of position and } \\
\text { authority - } \\
\text { committed by an official }\end{array}$ & 480 & 478 & $+1,7$ & 470 & 477 & $+1,5$ & 60,9 & 50.200 .578 \\
\hline IIlegal favoritism & & 1 & & & 1 & & 0,1 & \\
\hline Accepting bribes & 19 & 14 & & 19 & 14 & & 1,8 & 198.649 \\
\hline Bribery & 26 & 25 & $-26,3$ & 26 & 25 & $-26,3$ & 3,2 & 14.350 \\
\hline Influence trading & & 5 & $-3,8$ & & 5 & $-3,8$ & 0,6 & \\
\hline Total & 515 & 785 & $+52,4$ & 515 & & $+52,2$ & 100 & 53.309.307 \\
\hline
\end{tabular}

Source: Statistical overview of basic safety indicators and results of work in 2019, Ministry of the Interior of Republic of Croatia for 2019, March 2020

As can be seen from the table, as many as $61 \%$ of corruption offenses relate to "abuse of office", i.e. the offences are related to officials and subjects of state. If we take in consideration relative damage done by the corruption offences, we can see how that form of commission counts for $94,2 \%$ of all registered forms of offences. 


\section{Results}

We have used data on the entrepreneurial activity and corruption in order to determine association between level of corruption, intensity of entrepreneurial activity (approximated by the value of goods sold and number of active entrepreneurs) and level of motivation for entrepreneurial activity for six Croatian regions (Table 5).

Table 5. Corruption, intensity of entrepreneurial activity and entrepreneurial motivation in Croatia

\begin{tabular}{|c|c|c|c|c|c|c|c|}
\hline Region & $\begin{array}{c}\text { Value of sold } \\
\text { goods (\%) }\end{array}$ & $\begin{array}{c}\text { Rank of } \\
\text { intensity of } \\
\text { enterprenurial } \\
\text { activity }\end{array}$ & $\begin{array}{c}\text { Number of } \\
\text { enterprenurs by } \\
\text { regions \% }\end{array}$ & $\begin{array}{c}\text { Rank of intensity of } \\
\text { number of } \\
\text { enterprenurs by } \\
\text { regions }\end{array}$ & $\begin{array}{c}\text { Motivation } \\
\text { indeks }\end{array}$ & $\begin{array}{c}\text { Number of } \\
\text { corruption } \\
\text { offences \% }\end{array}$ & $\begin{array}{c}\text { Rank of of } \\
\text { corruption } \\
\text { offences }\end{array}$ \\
\hline Zagreb and surroundings & 27,99 & 1 & 39,84 & 1 & 2 & 12,23 & 3 \\
\hline Slavonia and Baranja & 11,52 & 4 & 8,12 & 5 & 5 & 6,37 & 5 \\
\hline Northern Croatia & 25,24 & 2 & 11,18 & 4 & 4 & 3,82 & 6 \\
\hline Lika and Banovina & 9,71 & 5 & 4,08 & 6 & 5 & 21,15 & 2 \\
\hline Istria, Primorje and Gorski & 18,96 & 3 & 17,00 & 3 & 1 & 7,90 & 4 \\
\hline Kotar & 6,58 & 6 & 19,77 & 2 & 3 & 48,53 & 1 \\
\hline Dalmatia & 100 & & 100 & & & 100 & \\
\hline Total & & & & &
\end{tabular}

Sources: Croatian Central Bureau of Statistics. (2018), IND-21/PRODCOM/G; Financial Agency (FINA). (2018), Analysis of financial results of entrepreneurs in Croatia; Singer et al. (2018); Ministry of the Interior of Republic of Croatia. (2020), Statistical overview of basic safety indicators and results of work in 2019, Ministry of the Interior of Republic of Croatia for 2019, March 2020

Association between ranks of number of corruptive offences and entrepreneurial activity approximated by the value of goods sold and number of companies in designated regions of Croatia were measured by Spearman's rank correlation coefficient.

A strong inverse correlation between trends was found ( $\mathrm{rs}=-0.60$, standard error of estimate: 1,673320053) (Figure 2) which leads to the conclusion that the stronger presence of corruption significantly negatively affects product sales, i.e. trade in the broadest sense

Corruption and Value of products sold

$Y=5,6-0,6^{*} x$

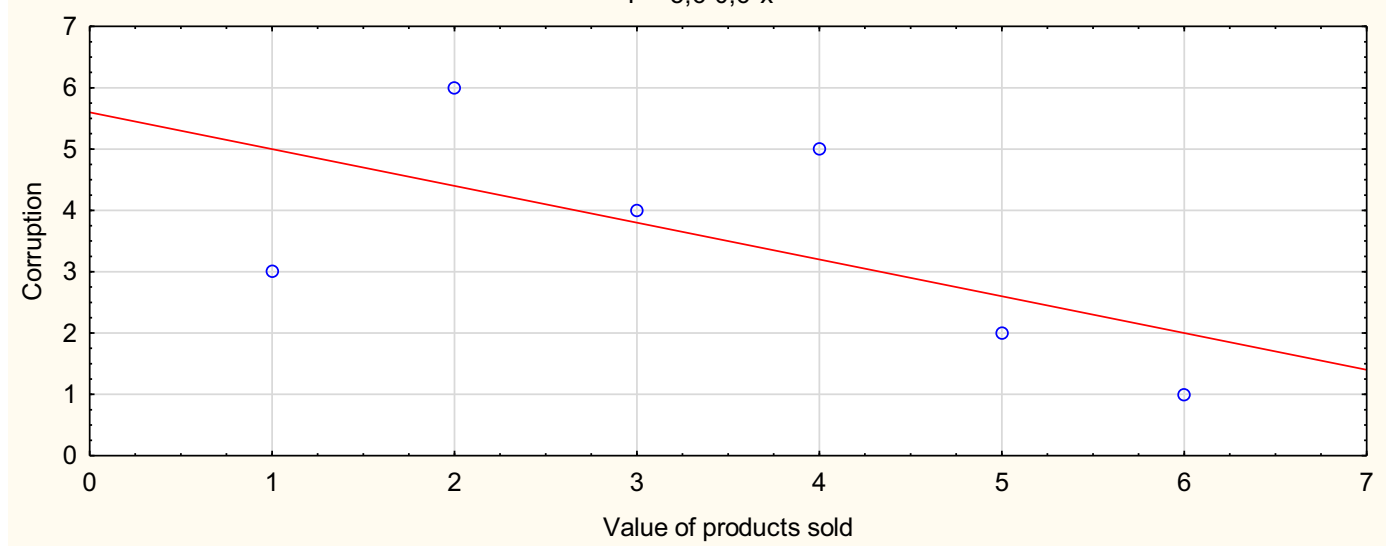

Fig. 2. Association between level of corruption approximated by the number of corruptive offences in each of Croatian regions and intensity of entrepreneurial activity approximated by relative value of sold products

On the other hand, Spearman's rank correlation coefficient between the number of corruptive offenses and the number of entrepreneurs in a specific region shows week positive correlation ( $\mathrm{rs}=0.257$, standard error of estimate: 2.021314989 ), as shown in Figure 3. 


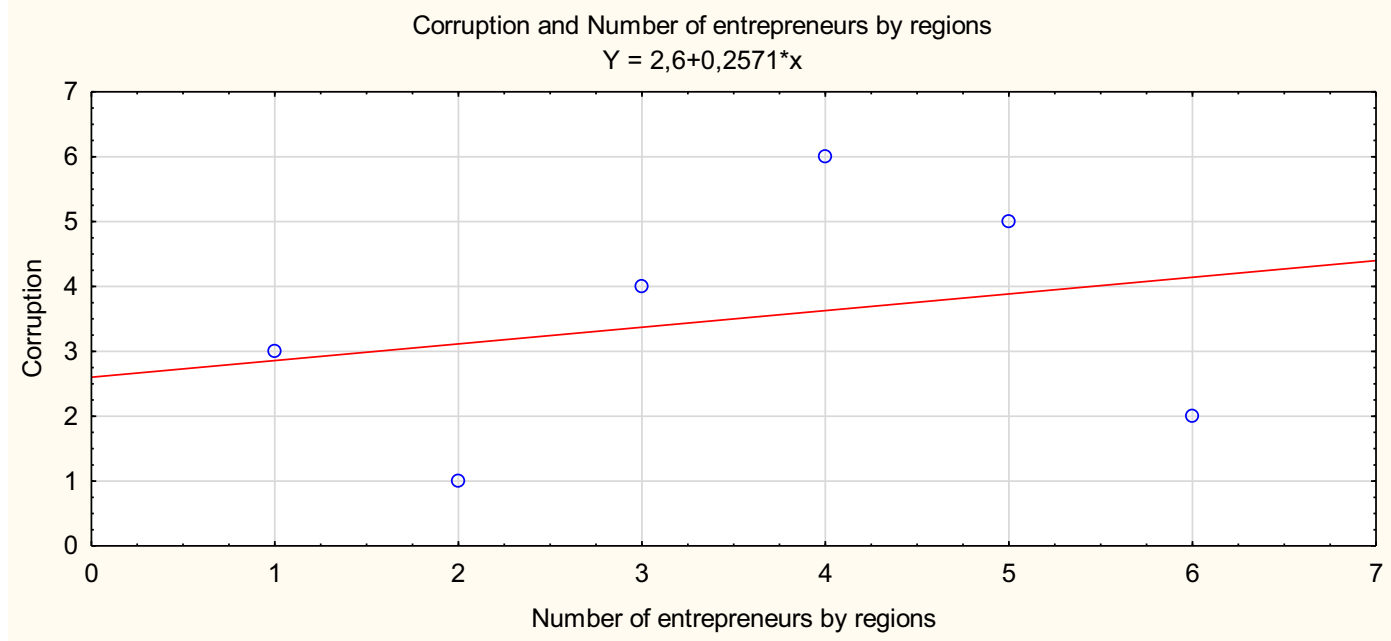

Fig. 3. Association between level of corruption approximated by the number of corruptive offences in each of Croatian regions and intensity of entrepreneurial activity approximated by number of entrepreneurs

Third association that the paper gives insight to is connection between corruption and motivation for starting entrepreneurial venture. Spearman's rank correlation coefficient between these two trends shows positive correlation of 0,314 (standard error of estimate: 1,985662898) as showed in Figure 4.

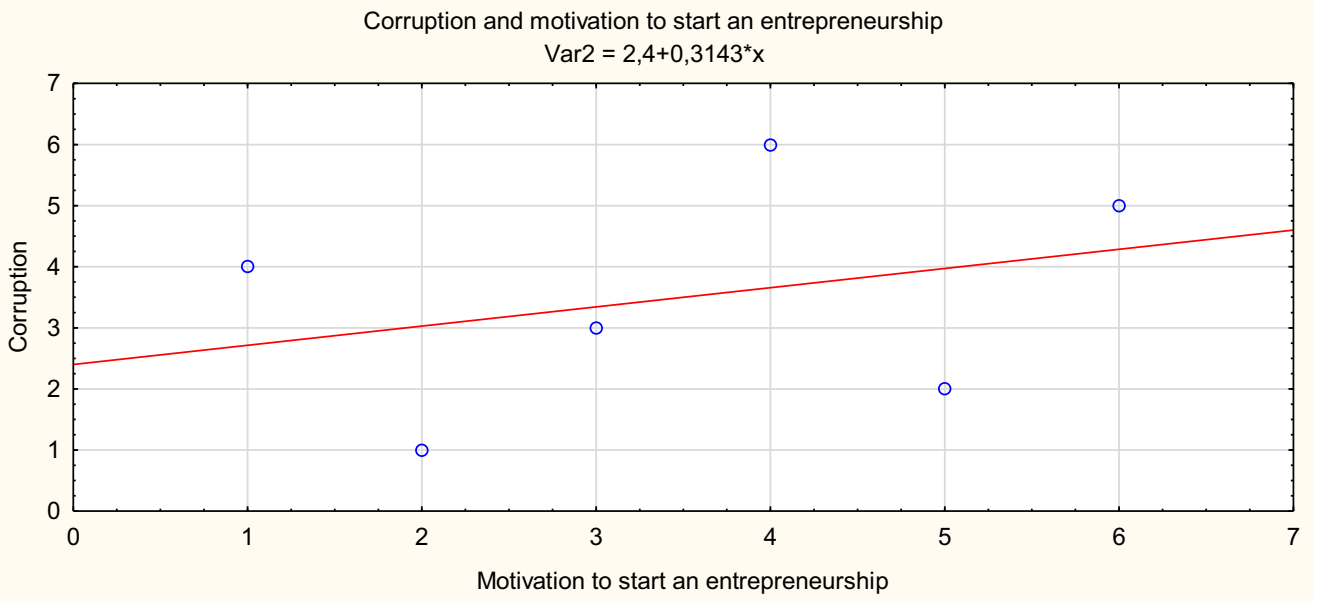

Fig. 4. Association between level of corruption approximated by the number of corruptive offences in each of Croatian regions and motivation for starting an entrepreneurial venture

\section{Conclusion}

Globalization today plays an important part in development of entrepreneurial activity in a specific area and in the specific industry, however besides globalization forces there are also other influences at work which focus more at the local influences. The paper argues how entrepreneurial development relies heavily on four factors: level of corruption, size of urban areas in which companies operate, industrial structure and influences of a wider, national, culture. Focus of this paper is on the influence of corruption, which is a significant social and economic issue that has crippling effect for entrepreneurship since it is restrictive 
for both entrepreneurial spirit and activity. Further on, the superiority of larger cities in generating advanced economies has been recognized since the time of the ancient Greek and medieval Italian city-states, however it is not clear if the same is applicable today as well. Third cornerstone of entrepreneurial development in main urban areas is the industrial structure of these areas. In Croatia that is quite important because regions of Dalmatia and Istria are quite dependent on tourism. Lastly, the values that drive entrepreneurial action and form entrepreneurial environments are embedded in wider national culture. The paper argues how pivotal issue in this respect in Croatia is the influence of egalitarian syndrome, a legacy of pre-modern agrarian communities, especially emphasized in post-communist countries since socialism proclaimed egalitarian moral values.

Due to the fact that the analysis of the entire set of influences would necessary go beyond the scope of one paper, we focus on the influence of corruption on entrepreneurial activity. In European economies in transition, corruption is relatively strong and has become a social fact up to the level of its acceptance as something that almost has to be part of society and the nation [24-25]. In essence, it gained importance due to the difficulty of transition from the "contract economy", which ruled in the former communist and totalitarian economies, and which after the collapse of these regimes in Europe did not have enough knowledge or strength to resist its social and economic escalation. With the development of the economy, in transition economies, in the direction of market orientation, it has begun to be understood that the role of corruption is disastrous in the long run and that it needs to be suppressed. Thus, inherited ignorance in the domain of market economy, which today is the sine qua non of any developed economy, is one of the important factors in the ubiquity of corruption in the Croatian economy and society.

The results of the research, which refer to six regions of Croatia, showed that the strength of corruption in the decision-making process and motivation to enter an entrepreneurial venture, as well as the representation of entrepreneurs in the economy at the regional level, is relatively small, although present. The fact that corruption is most present in political circles indicates its presence in the economy as a whole, which was confirmed in this research. That is, the category "sold products" refers to the Croatian economy as a whole, and therefore to large enterprises, especially state-owned ones

In accordance with the results of the research, as well as the fact that Croatia is ranked in the high third place in the EU economies in terms of corruption according to the CPI, just behind Romania and Bulgaria, corruption is posed as par excellence research question. In this regard, it is necessary to work more significantly on building stable economic national systems in economies in transition, and within these systems, special attention should be paid to the subsystem of supervision and controlling.

\section{References}

1. Reuber, B., Knight, G., Liesch, P., Zho, L. (2018). International entrepreneurship: The pursuit of entrepreneurial opportunities across national borders. Journal of International Business Studies, 49(4), 395-406

2. Shepherd, D. (2019). Researching the dark side, downside, and destructive side of entrepreneurial action: It's the compassionate thing to do. Academy of Management Discoveries, 5(3), 217-220.

3. McIntyre, D., Srinivan, A. 2017. Networks, platforms, and strategy: Emerging views and next steps. Strategic Management Journal, 38(1), 141-160.

4. Baron, R. A., Tang, T., Tang, Z., Zhang, Y. (2018). Bribes as Entrepreneurial Actions: Why Underdog Entrepreneurs Feel Compelled to Use Them. Journal of Business Venturing 33(6), 679-690. 
5. Bruton, G.D., Zahra, S.A., Cai, L. (2018). Examining Entrepreneurship through Indigenous Lenses. Entrepreneurship Theory and Practice 42(3), 351-361.

6. Clark, D. R., Li, D. Shepherd, D.A. (2018). Country Familiarity in the Initial Stage of Foreign Market Selection. Journal of International Business Studies 49(4), 442-472.

7. Shleifer, A., Vishny, R. (1993), Corruption. Quarterly Journal of Economics, 108(3), 599-617.

8. Sachs, J.D., Warner, A.M. (1997). Sources of Slow Growth in African Economies. Journal of African Economics, 6, 335-376.

9. Mauro, P. (1995), Corruption and Growth. Quarterly Journal of Economics, 110(3), 681-712.

10. Brunetti, A. (1997). Political Variables in Cross-Country Growth Analysis, in: Journal of Economic Surveys, 11(2), 163-190.

11. Kaufmann, D., Kraay, A., Zoido-Lobaton, P. (1999), Aggregating 18 Governance Indicators, World Bank, Policy Research Working Paper, No. 2195, Washington, D.C.

12. Leite, C., Weidmann, J. (2002). Does Mother Nature Corrupt? Natural Resources, Corruption, and Economic Growth, in: George T. Abed and Sanjeev Gupta (Ed.). Governance, Corruption, \& Economic Performance, International Monetary Fund, Publication Services, Washington, D.C. (pp. 159-196).

13. Gyimah-Brempong, K. (2002). Corruption, Economic Growth, and Income Inequality in Africa. Economics of Governance, 3(3), 183-209.

14. Neeman, Z., Paserman, D., Simhon, A. (2004), Corruption and Openness, Department of Economics. Hebrew University, Working Paper, 353.

15. Welsch, H. (2004). Corruption, growth, and the Environment: A Cross-Country Analysis. Environment and Development Economics, 9(5), 663-693.

16. Pellegrini, L., Gerlagh, R. (2004). Corruption's Effect on Growth and its Transmission Channels. Kyklos, 57, 429-456.

17. Belitski, M., Desai, S. (2016). Creativity, entrepreneurship and economic development: City-level evidence on creativity spillover of entrepreneurship. The Journal of Technology Transfer, 41(6), 1354-1376.

18. Spigel, B., Harrison, R. (2018). Toward a process theory of entrepreneurial ecosystems. Strategic Entrepreneurship Journal, 12(1), 151-168.

19. Budak, J, Rajh, E. (2014). Corruption as an obstacle for doing business in the Western Balkans: A business sector perspective. International Small Business Journal, 32(2), 140-157.

20. Dickel, P, Graeff, P. (2018). Entrepreneurs' propensity for corruption: A vignettebased factorial survey. Journal of Business Research, 89, 77-86

21. Xu, D., Zhou, K., Du, F. (2019). Deviant versus aspirational risk taking: The effects of performance feedback on bribery expenditure and R\&D intensity. The Academy of Management Journal, 62(4), 1226-1251.

22. Bosma N. Kelley D. (2019). Global Entrepreneurship Monitor 2018/2019. Global Report, GEM.

23. Singer, S., Šarlija, N., Pfeifer S., Oberman Peterka, S. (2018). What makes Croatia a (non)entrepreneurial country? GEM Croatia 2017, CEPOR - SMEs and Entrepreneurship Policy Center.

24. Holmes, L. (2013). Postcommunist Transitions and Corruption: Mapping Patterns. Social Research, 80(4), 1163-1186. 
25. Chiara A., Elodie D. (2020). Corruption and Life Satisfaction in Transition: Is Corruption a Social Norm in Eastern Europe? Social Indicators Research: An International and Interdisciplinary Journal for Quality-of-Life Measurement, 151(2), 723-766. 